\title{
Research about the Influential Factors of Insider Trading under the M\&A: Based on the Perspective of Corporate Governance
}

\author{
Dihui $\mathrm{Wu}^{1}, \mathrm{Du} \mathrm{Li}^{2}$
}

\begin{abstract}
By studying the influence factors of insider trading in the process of Mergers \& Acquisitions (M\&A)for 952 Chinese firms from 2001 to 2014 at the perspective of corporate governance, and puts forward relevant policy suggestions. The empirical results show that the reasonable arrangement of corporate governance structure can produce certain restrictions on insider trading; At the same time, the larger the M\&A size is, the more severe insider trading. This conclusion means that, under the current background of China, in order to protect the interests of investors, it is necessary to continue to adjust the governance structure and perfect the governance of listed companies; For the larger M\&A of listed companies, supervision departments should strengthen supervision andthe quality of information disclosure of listed companies to safeguard the rights and interests of investors.
\end{abstract}

Keywords: M\&A, insider trading, company governance, interests of investors, governance structure

\section{Introduction}

Insider trading is one of serious irregularities in the securities market, the "securities law" promulgated in 1999 in China, "the recognition method of insider trading" promulgated in 2007, and the "On strike and prevention and control in accordance with the capital market insider trading"released On November 18, 2010 all had made detailed rules for the behavior characteristics, punishment and identification of insider trading. Despite the strict insider trading legislation, insiders will still engage in inside trading at the risk of violating the law under the huge interests to infringe on investor's legitimate rights and interests for some reasons. First, companies often adjust the corresponding assets, inject high quality assets and update the management team after M\&A(Huacheng Wang, Baohong Yue, 2009) ${ }^{[1]}$. Second, the special features such as long operation period, complicated action structure, long inside information chain and complicated insiders of M\&A may cause serious information leakage, and it is hard to supervise and collect evidences of insiders for supervision departments(Rujia Li, 2013) $)^{[2]}$.

Corporate governance is defined as a series of mechanisms to prevent outside shareholders being violated by company insiders in the article of Shleifer and Vishny $(1997)^{[3]}$ Theoretical research and practical experience have proved that perfect corporate governance will protect outsideinvestors, prevent corporate insiders from infringing on the legitimate interests of outside investors. And fragile corporate governance create an excellent opportunity without any doubt for the insiders to engage in inside trading violations of laws and infringe on investor's legitimate rights and interests seriously (Denis and McConnell, 2003 $)^{[4]}$. WeihuaZhu (2008) ${ }^{[5]}$ and Qiming Tang, Zhang Yun $(2009)^{[6]}$ found that insider trading is caused largely by fragile corporate governance and internal control. Thus, it is necessary to verify the relations between corporate governance and insider trading systematically.
In order to study the relationship between corporate governance and insider trading, we need to put the conflicts of interest within the company as a starting point, then clarify the interest relationship between the various stakeholders. These conflicts of interest include conflict of interest between shareholders and managers, between shareholders and creditors, between large shareholders and minority shareholders, which mainlyreflected in the aspects of the executive pay, ownership structure and capital structure. Therefore,this paper adopt empirical analysis to show how executive pay, ownership structure and capital structure affect the insider trading. In addition, it also analyzes the impact of merger-scale on the insider trading, thereby to provide an effective proposal to control insider trading occurred.

\section{Theoretical Analysis and Research Hypothesis}

2.1 Corporate governance and insider trading

\subsubsection{Equity structure}

Many studies on corporate governance agree that concentration of ownership structure is not a kind of effective mechanism and the reason is that the big shareholders will spare no efforts to maximize their own interests at risk violating of the law,and concentration of ownership will affect the nature of the contract, resulting agency problems. La Porta et al.(1997) ${ }^{[7]}$ found that big shareholder could obtain greater control over the control of listed companies with a smaller cash flow, and the largest shareholder would transfer the resources of listed companies by using the control to infringe on investors . In other words, the controlling shareholder control much larger capital funding compared to their own investment funds on the one hand, so that the controlling shareholders have an incentive to pinch the interest of other shareholders; On the other hand, the controlling shareholder widely involved in the

\section{Volume 5 Issue 5, May 2016}




\section{International Journal of Science and Research (IJSR) \\ ISSN (Online): 2319-7064}

Index Copernicus Value (2013): 6.14 | Impact Factor (2015): 6.391

actual operation and management of the company, which provide actual possibility for their pinching behavior.

However, (Grossman and Hart, 1980) ${ }^{[8]}$ believe that dispersed ownership structure makes it easy for shareholder to lose incentives to participation of corporate governance and incentives of driving growth in value of the company. (Jensen, 1989)hold that dispersed ownership structure will lead to internal governance system failure, and easy to produce "internal control" issues in the management. In the case of lack of shareholders' supervision, on the one hand, the agent manager may use its hidden information and actions to maximize their personal benefit, which against the interests of the company and its shareholders in some cases; on the other hand, conspiracy between major shareholders and major shareholders may transfer the interests of minority shareholders. Therefore, considering the fact of the relationship between control, restrict ownership and insider trading to be tested, we propose the following research hypothesis $\mathrm{H} 1$ :

H1A: The greater the control (control ratio) is, the greater the likelihood of the occurrence of insider trading of listed companies is.

H1B: The lower the level of equity checks and balances is, the greater the likelihood of the occurrence of insider trading of listed companies is.

\subsubsection{Board Composition}

The board is the biggest internal control mechanism to supervise management behavior, and the composition of the board members has an important influence on the efficiency of supervise management behavior. Jensen $(1993)^{[9]}$ found that an effective board organizational model should maintain a smaller board size, If the scale of the board is too large, then is not effective supervisor of management behavior.

Besides, Board composition theory is generally believed that the higher the proportion of independent directors is, the higher the efficiency of the supervision of the management behaviorwill be. And the proportion of independent directors on the board is of great important in the case that large shareholders of listed companies have absolute advantage of the company over other shareholders. However, those people who listen more to the chairman or CEO would get more chance to be the independent directors. In other words, if the company's CEO have controlled or partially controlled the board, then it is difficult for the board to play an independent and active monitoring role. Thus, the "independent" directors are not independent. Naturally, it is necessary to consider the impact of the proportion of independent directors and the board size on insider trading. We propose the following research hypothesis $\mathrm{H} 2$ :

H2A: The greater the board size is, the greater the likelihood of the occurrence of insider trading of listed companies is.

$\mathrm{H} 2 \mathrm{~B}$ : The lower the board independence is, the greater the likelihood of the occurrence of insider trading of listed companies is.

\subsubsection{Executive compensation}

Executive compensation incentive contract is a kind of corporate governance to effectively alleviate the managers' seeking private benefit behavior, such as insider trading and "be lazy" (Changyun Wang, Yanmei Sun, 2010) ${ }^{[10]}$. A valid pay contracts should make the interests of managers and shareholders reach unanimity. The theoretical model of Neo(1997) ${ }^{[11]}$ support that there is substitution effect between dominant managers pay and their insider trading opportunities. In other words, the shareholders will provides lower pay when they acquiesce insider trading; In any of the same fixed salary levels, insider trading can increase motives of managers. However, insider trading might induce managers to choose some high-yield but low-risk projects; at this time, insider trading is no alternative action on executive pay, but may increase the incentive compensation costs. So Neo (1997), Macy (1991) and other scholars believe that under the action of risk-averse and maintaining the reputation, managers would not execute those high-yield but low-risk projects. The core of the debate above is that the relationship between insider trading and incentive pay iin the end is alternative or complementary, there is no consistent conclusion. So we propose the following research hypothesis $\mathrm{H} 3$ :

H3: The higher the executive compensation is, the greater the likelihood of the occurrence of insider trading of listed companies.

\subsection{M \& A scale and insider trading}

For different sizes of M\&A transactions, the degree of market attention is different, so are the information asymmetry, the profit space and the probability of the occurrence of insider trading are not the same yet. First, the lager acquisitions means more improved assets would be inject into the company, and there would be more gimmicks, which means the company would get more attention, leading to greater trading volume. The huge volume of transactions in favor of insiders to sell stocks to get a huge excess yield in time; Second, the larger the scale of M\&A is, the higher the complexity of the acquisition of assets is, the higher the information asymmetry between small investors and insiders is, leading to stronger arbitrage motivation. So this paper put forward the hypothesis H4:

H4: The larger the scale of M\&A is, the greater the likelihood of the occurrence of insider trading of listed companies.

\section{Data Selection, Variable Definitions and Model Building}

\subsection{Data Selection}

The paper is based on the data of equity agreement transfer from China Center for Economic Research (CCER) covering the period from 2001 to 2014. Partially missing data are supplemented by annual reports. To ensure the availability and accuracy of the data, it was screened based 


\section{International Journal of Science and Research (IJSR) \\ ISSN (Online): 2319-7064 \\ Index Copernicus Value (2013): 6.14 | Impact Factor (2015): 6.391}

on the following criteria: (1) Excluding the companies of financial sector, funds and insurance; (2) Excluding the IPO, ST and ST * Companies; (3) Excluding the companies which lack of related data; (4) The amount of M\&A activity involved need to acquire at least $5 \%$ of the total assets to ensure that the trading activities have an important impact on the business performance; (5) We select the first M\&A activity which separated last M\&A activity by more than six months in the same year, otherwise removed all. After the above screening, we obtained 952 valid samples finally.

\subsection{Variable definitions}

\subsubsection{The proxy variables of insider trading}

Illegal insider trading behavior is defined as insiders trade based on inside information, with its significant and nonpublic features, it has a significant impact on the stock price. Besides, inside information is the foundation of information asymmetry between insiders and other investors, which is also one of the basic reasons of insider trading. This paper use the event study method to calculate the cumulative abnormal yield of insider trading as a proxy variable to measure the yield of insider trading during the period.

As to the selection of event day, some studies choose the first officially declaration date as the event day (Zhang Wei, Gaofeng Zhou, 2004), other studies choose the day after M\&A finished as the event day(Hongjun Zhu, 2005) ${ }^{[12]}$. However, taking into account the fact that the moment the information of M\&A has been disclosed the first time declared, the market has already responded to the information. So it's better to choose the first officially declaration date as the event day. In this paper, the first announcement date for the event 0 , the event window was $(-10,10)$, and the estimated window was $(-250,-11)$. Specific calculation formula of cumulative abnormal yield as follows:

We use the market model to calculate daily excess

yield.First, we calculate the value of $\alpha$ and $\beta$ of every company byformula (1) with daily yield of every stock and daily yield of the market in the estimation period(-250,-11). And $R_{i, t}$ is the yield of stock $i$ on day $t, R_{m, t}$ is the market yield on day $\mathrm{t}$.

$$
R_{i, t}=\alpha_{i}+\beta_{i} \times R_{m, t}+\varepsilon_{i, t}
$$

Then we calculate the daily abnormal yield on day $(-10,10)$

by formula (2) with $\alpha$ and $\beta$.Among them, $\mathrm{AR}_{\mathrm{i}, \mathrm{t}}$ is the abnormal yield of stock $i$ on day $t, E\left(R_{i, t}\right)$ is expected yield of stock $\mathrm{i}$ on day $\mathrm{t}$ by market model.

$$
A R_{i, t}=R_{i, t}-E\left(R_{i, t}\right)=R_{i, t}-\left(\alpha_{i}+\beta_{i} \times R_{m, t}\right)
$$

Finally, we calculate cumulative abnormal return (CAR) of every stock in the period $(-10,10)$.

$$
C A R_{i}=\sum_{t=x_{l}}^{x_{2}} A R_{i, t}
$$

3.2.2 The proxy variables of corporate governance Draw on existing literature, we measure the status of corporate governance by ownership structure, board composition and executive compensation. Include six variables: Control, Mshare, Constrain, Indirector, Board and Salary in detail.

\subsubsection{The model building}

Learned from other researchers' papers related to corporate governance and insider trading, we set the model as follows:

$C A R_{i}=\alpha_{0}+\alpha_{l}$ Control $+\alpha_{2}$ Mshare $+\alpha_{3}$ Constrain + $\alpha_{4}$ Indirector $+\alpha_{5}$ Board $+\alpha_{6}$ Salary $+\alpha_{7}$ M_size $+\alpha_{8}$ Size $+\alpha_{9}$ Debt $+\alpha_{10}$ Roa $+\alpha_{11}$ Flow $+\varepsilon_{i}$

We choose Debt, Roa, Size and Cash as control variables to prevent the model being disturbed by other factors. The choice and definition of these control variables keep the

\begin{tabular}{|c|c|c|}
\hline & Variable & Definition \\
\hline Dependent Variable & CAR & Cumulative abnormal return of every stock in the period $(-10,10)$ \\
\hline \multirow{3}{*}{ Ownership Structure } & Control & The share proportion of the controlling shareholder \\
\hline & Mshare & The share proportion of company executives . \\
\hline & Constrain & $\begin{array}{c}\text { The ratio of the largest shareholder's share proportion and the second largest shareholder's share } \\
\text { proportion }\end{array}$ \\
\hline \multirow{2}{*}{ Board Composition } & Indirector & The ratio of independent directors and the board of directors \\
\hline & Board & The number of members of the board \\
\hline Executive Compensation & Salary & The natural logarithm of average remuneration of the top three executives \\
\hline M\&A Size & M_size & The proportion of equity M\&A occurred \\
\hline \multirow{4}{*}{ Control Variables } & Size & The natural logarithm of total assets at the end of the year \\
\hline & Debt & The ratio of debt to total assets at the end of the year \\
\hline & Roa & The ratio of net profit to total assets at the end of the year \\
\hline & Flow & The ratio of net operating cash flow and total assets at the end of the year \\
\hline
\end{tabular}
same with existing literature (table 1).

Table 1: Variables and definition 


\section{International Journal of Science and Research (IJSR) \\ ISSN (Online): 2319-7064}

Index Copernicus Value (2013): 6.14 | Impact Factor (2015): 6.391

\section{The Empirical Analysis Results}

\subsection{Descriptive Statistics}

Table 2 shows the descriptive statistics of all variables. We can find the mean of CAR reached 2.5657, which means there will be a greater excess returns in the process of M\&A. In terms of ownership structure, the average executives holding is only $0.58 \%$, but the maximum has reached $57.08 \%$, which means that equity ratio of most executives of listed companies is relatively low, while few of them is especially high. The proportion of the largest shareholder on average up to $35.04 \%$, the highest even reached $84.97 \%$, which reflects that the ownership structure of listed companies in the sample are too concentrated. In the board of directors, the mean of the ratio of independent directors and the board of directorsreaches $49.81 \%$, there are also part of the samples which don't set up independent directors.

Table 2: Descriptive statistics of the main variables in the model

\begin{tabular}{|c|c|c|c|c|c|}
\hline Variable & $\begin{array}{c}\text { Sample } \\
\text { size }\end{array}$ & $\begin{array}{c}\text { Mini- } \\
\text { mum }\end{array}$ & $\begin{array}{c}\text { Maxi- } \\
\text { mum }\end{array}$ & Average & $\begin{array}{c}\text { Standard } \\
\text { deviation }\end{array}$ \\
\hline CAR & 952 & -37.610 & 69.760 & 2.566 & 12.509 \\
\hline Control & 952 & 7.930 & 84.970 & 35.040 & 14.875 \\
\hline Mshare & 952 & 0.000 & 57.080 & 0.581 & 3.762 \\
\hline Constrain & 952 & 1.000 & 268.420 & 13.224 & 31.927 \\
\hline Indirector & 952 & 0.000 & 4.000 & 0.498 & 0.369 \\
\hline Board & 952 & 1.000 & 17.000 & 6.659 & 1.942 \\
\hline Salary & 952 & 0.510 & 3.330 & 1.882 & 0.692 \\
\hline M_size & 952 & 5.000 & 83.750 & 24.649 & 16.281 \\
\hline Size & 952 & 18.490 & 25.400 & 21.111 & 0.989 \\
\hline Debt & 952 & 0.010 & 3.090 & 0.473 & 0.214 \\
\hline Roa & 952 & -3.1400 & 0.2500 & 0.0159 & 0.1334 \\
\hline Flow & 952 & -0.4500 & 4.2200 & 0.0515 & 1.5976 \\
\hline
\end{tabular}

4.2 Corporate governance, scale of $M \& A$ and insider trading

Table 3 is the test result of relationship among corporate governance, scale of M\&A and insider trading. The first to fifth column are the regression results of the relationship respectively between ownership structure and insider trading, board composition and insider trading, executive compensation and insider trading, scale of M\&A and insider trading, all variables and insider trading.

The 1th column shows the coefficients of "Mshare" and Constrain are positive under the premise of other conditions being kept the same, which means the higher the proportion of executives shareholding, the more serious insider trading; the higher the constrain, the more serious insider trading. But it is inconsistent with the theoretical expectations of Shleifer and Vishny (1986), we don't find significant evidence to prove that the higher proportion of large shareholders leads to the seriousness of insider trading. Taking into account the size of the board may exist in non-monotonic effect (Abbott, Parker and Peters, 2000) ${ }^{[13]}$, we add Board $^{2}$ into the model. We find significant relationship between board size and insider trading from the
2 th column. The coefficient of "Board" is significant negative while "Board" is significant positive. It shows that the increase in the number of board of directors help curb insider trading in general, but the positive influence have been counterbalanced by the increased cost of communication and coordination. According to the calculation principle of the inflection point of function, 9 is the best size of the "Board". The coefficient of "Indirector" in the 3 th column is significant positive, which means that the lower executive compensation is, the more serious insider trading is. The coefficient of "M_size" in the 4th column is significant positive, which means that the larger scale of M\&A, the more serious insider trading. The coefficients of the 5th column keep the same with theabove result.

Table 3 The inspection of the relation among corporate governance, $M \& A$ scale and insider trading.

\begin{tabular}{|c|c|c|c|c|c|}
\hline & \begin{tabular}{|c|} 
Equity \\
structure
\end{tabular} & \begin{tabular}{|c|} 
Board \\
composition
\end{tabular} & $\begin{array}{c}\text { Executive } \\
\text { compensation }\end{array}$ & $\begin{array}{c}\text { Scale of } \\
\text { M\&A }\end{array}$ & $\begin{array}{c}\text { All } \\
\text { variables }\end{array}$ \\
\hline Control & $\begin{array}{c}-0.028 \\
(-0.971)\end{array}$ & & & & $\begin{array}{c}-0.021 \\
(-0.621)\end{array}$ \\
\hline Mshare & \begin{tabular}{|c|}
$0.271 * *$ \\
$(2.194)$ \\
\end{tabular} & & & & $\begin{array}{l}0.186^{*} \\
(1.714) \\
\end{array}$ \\
\hline Constrain & $\begin{array}{c}0.021 * * \\
(2.507)\end{array}$ & & & & $\begin{array}{c}0.007 \\
(0.855)\end{array}$ \\
\hline Indirector & & $\begin{array}{l}2.425^{*} \\
(2.044) \\
\end{array}$ & & & $\begin{array}{l}3.833 * * \\
(2.336)\end{array}$ \\
\hline Board & & $\begin{array}{l}-2.685 * * \\
(-2.050)\end{array}$ & & & $\begin{array}{l}-2.441^{*} \\
(-1.895)\end{array}$ \\
\hline Board2 & & $\begin{array}{c}0.148 \\
(1.740 *) \\
\end{array}$ & & & $\begin{array}{l}0.138^{*} \\
(1.662) \\
\end{array}$ \\
\hline Salary & & & $\begin{array}{l}-1.290 * * \\
(-2.245)\end{array}$ & & $\begin{array}{l}-2.941^{*} \\
(-1.675)\end{array}$ \\
\hline M_size & & & & $\begin{array}{c}0.053 * * \\
(2.157)\end{array}$ & $\begin{array}{l}0.150 * \\
(1.912) \\
\end{array}$ \\
\hline Size & $\begin{array}{l}0.975^{*} \\
(1.885)\end{array}$ & $\begin{array}{c}0.510 \\
(1.131)\end{array}$ & $\begin{array}{l}0.908^{* *} \\
(2.076)\end{array}$ & $\begin{array}{l}0.753^{*} \\
(1.667)\end{array}$ & $\begin{array}{c}0.455 \\
(0.965)\end{array}$ \\
\hline Debt & $\begin{array}{l}4.556 * * \\
(2.003) \\
\end{array}$ & $\begin{array}{l}4.189 * \\
(1.763)\end{array}$ & $\begin{array}{c}2.708 \\
(1.128) \\
\end{array}$ & $\begin{array}{l}3.967^{*} \\
(1.691) \\
\end{array}$ & \begin{tabular}{|c|}
$5.057 * *$ \\
$(2.097)$ \\
\end{tabular} \\
\hline Roa & $\begin{array}{l}-11.034 * \\
(-1.655)\end{array}$ & $\begin{array}{l}-11.463^{*} \\
(-1.698) \\
\end{array}$ & $\begin{array}{c}-12.896^{*} \\
(-1.861)\end{array}$ & \begin{tabular}{|c|}
$-13.859 * *$ \\
$(-1.985)$
\end{tabular} & $\begin{array}{c}-9.208 \\
(-1.348)\end{array}$ \\
\hline Flow & $\begin{array}{c}-2.004 \\
(-0.427) \\
\end{array}$ & $\begin{array}{c}5.814 \\
(1.183) \\
\end{array}$ & $\begin{array}{c}2.570 \\
(0.490) \\
\end{array}$ & $\begin{array}{c}-2.338 \\
(-0.471) \\
\end{array}$ & $\begin{array}{c}3.634 \\
(0.733) \\
\end{array}$ \\
\hline $\mathrm{C}$ & $\begin{array}{l}-16.180 * \\
(-1.918) \\
\end{array}$ & $\begin{array}{l}-0.667 * \\
(-0.069) \\
\end{array}$ & $\begin{array}{c}-15.993^{*} \\
(-1.825) \\
\end{array}$ & \begin{tabular}{|c|}
$-16.362 *$ \\
$(-1.806)$ \\
\end{tabular} & $\begin{array}{c}1.063 \\
(0.106) \\
\end{array}$ \\
\hline Adj-R2 & 0.021 & 0.028 & 0.012 & 0.018 & 0.032 \\
\hline$F$ & $\begin{array}{c}3.901 * * \\
*\end{array}$ & $5.010 * * *$ & $3.241 * * *$ & $4.398 * * *$ & $3.614 * * *$ \\
\hline Obs & 952 & 952 & 952 & 952 & 952 \\
\hline
\end{tabular}

\section{The Conclusion and Suggestion}

The result of this article shows that reasonable arrangements of corporate governing mechanism can restrain insider trading to some extent. In practical terms, appropriate size of the board and higher ratio of independent director can help to reduce the occurrence and cumulative abnormal 


\section{International Journal of Science and Research (IJSR) \\ ISSN (Online): 2319-7064}

Index Copernicus Value (2013): 6.14 | Impact Factor (2015): 6.391

return of insider trading; High proportion of executives shareholding will increase the risk of insider trading; "Constrain" can effectively restrict the occurrence of insider trading; Executive incentive can effectively reduce the occurrence of insider trading, and the larger scale M\&A is, the more serious insider trading is.

The conclusion means that in order to protect the legitimate rights of small investors and duce the occurrence of insider trading in the background of the current system, it's necessary to continue to adjust the governance structure of listed companies and improve the level of governance of listed companies. For example, design a more reasonable size of the Board (limited to about 9), strengthen the Independent Director System, reduce the proportion of executives holding and intensify efforts of "Constrain". At the same time, for large-scale M\&A of listed companies, regulatory authorities should strengthen supervision and improve information disclosure quality of companies to better protect the rights and interests of investors.

\section{References}

[1] Huacheng Wang, Baohong Yue. Market reaction and market efficiency of information disclosure: from the perspective of the transfer of control $[\mathrm{J}]$. Journal of Southeast University(philosophy and social science), 2009(3)

[2] Rujia li. The legal regulation of insider dealing in the process of merger and reorganization of quoted companies [D]. Master Thesis of Central South University, 2013

[3] Shleifer A. and Vishny R.W., A Survey of Corporate Governance[J]. The Journal of Finance, 1997, 52(2): 737-783.

[4] Denis D.K. and McConnell J. J., International Corporate Governance[J]. Journal of Financial and Quantitative Analysis, 2003, (38):1-36.

[5] Weihua Zhu. Corporate Governance and Insider Trading Regulation Efficiency [J].Economics (quarterly),2009, 1: 271-288.

[6] Qiming Tang, Zhang Yun. A research on illegal insider trading of Chinese stock market from the perspective of corporate Governance [J].Journal of Financial Research, 2009, 6: 144-160

[7] Porta L, F. L R, Shleifer A, et al., Legal determinants of external finance? Journal of Finance[J]. Social Science Electronic Publishing, 1997, volume 52(3):1131-1150(20).

[8] Grossman S.J., Hart O.D., Take-Over Bids, the Free Rider Problem, and the Theory of the Corporation[J]. Bell Journal of Economics, 1980, 11(1):42-64.

[9] Michael C. Jensen., The Modern Industrial Revolution, Exit, and the Failure of Internal Control Systems[J]. The Journal of Finance, 1993,48(3): 831-880.

[10] Changyun Wang, Yanmei Sun. A Study on Conflicts among Agents, on Corporate Governance and on Listed Companies' Fraud in Financial Statement [J].Management World, 2010, 7: 130-143

[11] Noe H.T., Insider Trading and the Problem of Corporate
Agency[J]. Journal of Law , Economics and Organization, 1997, 13: 287-318.

[12] Hongjun Zhu, Wang Hui. The Economic Consequences of the Fair Disclosure of Information [J].Management World, 2009(2): 23-35

[13] Abbott L.J., Parker S. and Peters G.F., The Effectiveness of Blue Ribbon Committee Recommendations in Mitigating Financial Misstatements : An Empirical Study",www.ssrn.com , 2000

\section{Author Profile}

Dihui Wu,Master, school of Economics and Management, Xidian University, Xian 710071, China

Li Du,Associate Professor,school of Economics and Management, Xidian University, Xian 710071, China 